\title{
MACROZOOBENTHOS DIVERSITY OF SAI RIVER AT RAEBARELI, INDIA
}

\author{
${ }^{1}$ Daisy Rani* and ${ }^{2}$ Sunita Arya \\ ${ }^{1}$ Department of Zoology Feroze Gandhi PG College, Raebareli (U.P.) \\ ${ }^{2}$ Department of Zoology DG PG College, Kanpur (U.P.)
}

\section{Research Paper}

Received: 02.11.2021

Revised: 18.11.2021

Accepted: 29.11.2021

\begin{abstract}
Macrozoobenthos are the best indicators of the stress in the aquatic ecosystem. Distribution of macrozoobenthos is determined by a number of factors such as physical nature of the substratum, depth, nutritive content of the water body. Present study was conducted to assess the diversity of macrozoobenthos of Sai River, Raebareli, Uttar Pradesh during July 2020 to June 2021. During the present investigation, a total number of 24genera of macrozoobenthic fauna were recorded from one year of investigation. Observations revealed that phylum Mollusca acquires dominant position with $45.83 \%$ of total faunal composition while phylum Annelida constitutes $29.16 \%$ and comes on second position whereas, least faunal abundance was found from phylum Arthropoda which contributes about $25 \%$.
\end{abstract}

Keywords: Diversity, Macrozoobenthos, Sai River.

\section{INTRODUCTION}

India is endowed with vast freshwater consisting 45,000 $\mathrm{km}$ of rivers, 26,334 km of canals, 2.36 million hectares of ponds and tanks, 2.05 million hectares of reservoirs and $5,82,86,000$ hectares of wetlands (Rani and Kumar, 2020).

River ecosystems (rivers capes) encompass ecological, social and economic processes (ecosystem functions) that interconnect organisms (ecosystem structure) including humans and helpful in maintaining the biodiversity. The genetic diversity acts as a buffer for biodiversity (Ashok, 2017)which helps in maintaining the ecological balance. The biodiversity has different levels, values and challenges (Ashok, 2016; Arya, 2021). There is a necessity of ecological balance for widespread biodiversity and the biodiversity loss has ecological impact (Verma 2017, 2018a; Kumar and Verma, 2017). The ecological balance is an indispensable need for human survival (Verma, 2018b). The climate change has a huge impact on biodiversity, sustainable development(Prakash and Srivastava, 2019; Prakash, 2021; Verma, 2021) and farmers' practice (Mandal and Singh, 2020). The river water is useful both for sustainable and unsustainable agriculture but pollution not only badly affect the agriculture but also aquatic biota (Kalalet al., 2021; Goswamiet al., 2021). The unsustainable agriculture has multiple effects (Verma, 2018a). In general, rivers have good aquatic resources (Chakraborty et al., 2021a, 2021b).

Macrozoobenthos being diverse in nature, react strongly and often predictably to human influences in aquatic ecosystem. They act as a viable tool for biological monitoring of freshwater ecosystems as they have wide range of sensitivities to change in both water quality and habitats (Thokeret al., 2015). Macrozoobenthos form the basis of the trophic level and any negative effect caused by pollution in the community structure can in turn affect trophic relationships. Macrobenthic invertebrates act as food for many aquatic birds and fishes. Different species comprise distinct functional groups that provide ecological integrity. In some cases, these functional groups may be represented by only a few species, so that any loss of species diversity could be detrimental to continued ecosystem functioning. Thus, it is increasingly becoming

*Corresponding author: ranidaisy6@gmail.com 
important to protect macrozoobenthic communities owing to their immense importance in their natural habitats.

The macrozoobenthos of freshwater wetlands provide significant support to the aquatic food web and contribute to ecosystem stability through sustenance of cultivatable fish, aquatic birds and other aquatic life. Their composition, abundance and distribution pattern acts as an ecosystem index, thereby indicating trophic structure, water quality and eutrophication level of the water bodies(Singh and Prakash, 2021).

A review of literature revealed that many researchers have studied on various waterbodies of Uttar Pradesh with respect to limnology and biodiversity of fishes in U.P. (Verma, 2016a, 2016b, 2020; Prakashet al., 2020; Prakash, 2020a, 2020b; Rani and Kumar, 2020; Sanjay and Prakash, 2020; Sugumaranet al., 2020). Benthic diversity of lentic waterbodies were studied by many ecologists in India (Sirajet al.,2010;Verma and Prakash, 2018; Prakash,2020c) and there is a need to obtain biological information on the lotic water body which are under pressure due to population growth and urbanization. Keeping this in mind, an attempt has been made to document macrozoobenthic diversity of Sai River at Raebareli. The present survey was conducted once in a month for a period of one year during July 2020 to June 2021 on three collection sites of Raebareli district of, U.P. to find out macrozoobenthos diversity.

\section{MATERIALSAND METHODS}

Study area: The study area, Raebareli $\left(80^{\circ} 41^{\prime}\right.$ to $81^{\circ} 34$ / N , altitude and $25^{\circ} 43^{\prime} 48$ to $26^{\circ} 20^{\prime} 18 \mathrm{E}$ longitude) district is situated in south region of U.P. Sai river is the main river traversing in this area and plays a vital role in the topography.

The river Sai originates at the sprawling pond on the hilltop at Parsoi, a village in the Hardoi district. It separates the region of Lucknow from Unnao. The river flows south by Raebareli, comes into the region of Pratapgarh and Jaunpur through the west, then turns east and touches the Ghuisarnath Dham. From there it touches another ChandikaDham. Most of the districts of Uttar Pradesh are situated on the banks of the Sai River. Shani Dev Dham is located on banks of the Sai River at Parsadepur.
The sediment samples were collected monthly and dried to constant weight in an oven at $105^{\circ}-110^{\circ} \mathrm{C}$. The sand, silt and clay were determined by pipette method (Piper,1966). The soil organic carbon and available phosphorus were estimated by Trivedyet al. (1987). The available nitrogen was determined by alkaline permanganate method (Subbiah and Asija, 1956). The $\mathrm{pH}$ was determined in 1:5 soil water suspension by $\mathrm{pH}$ meter.

The sediment samples were collected monthly from the bottom at three stations during morning time by using Peterson Grabe mud sampler. The collected samples were sieved through $0.5 \mathrm{~mm}$ sieve (Ankar and Elmgreen, 1976). The materials which retained on sieve were collected and from it benthic organisms were stored out with the help of forceps and brushes. These were collected in narrow mouthed plastic bottle, containing $4 \%$ formalin and $70 \%$ alcohol as preservative depending upon the type of organisms to be preserved. The soft-bodied organisms were preserved in $70 \%$ alcohol while the shelled organisms like mollusks in 4\% formalin. All macro fauna of bottle were identified with the help of available key and manuals Neetham and Needham(1962), Borroret al. (1976) and Pennak (1989) under the light microscope. The population of organisms was counted and number of individuals of a species per sample and was expressed as number $/ \mathrm{m}^{2}$.

\section{RESULTS AND DISCUSSION}

A total of 24 genera were found from the three sampling sites belonging to three phylaviz., Mollusca, Annelida and Arthropoda. All these are eucoelomate phyla (Verma and Prakash, 2020). Among them 11 species of molluscan community was represented by three classes viz., Gastropoda, Pelecypoda and Bivalvia. Gastropoda was represented by six genera followed by Class Pelecypoda (three genera) and Bivalvia(two genera). Whereas, Annelidan community was represented by two classes viz., Oligochaeta and Hirudinidae and Arthropodians belongs to three classes, viz.,Insecta, Crustacea and Arachnida (Table 1). The distribution of macrozoobenthos at sampling site I was maximum from all the three stations and 18genera were recorded. Phylum Mollusca was in dominated condition than Annelida and Arthropoda. At sampling site III distribution of macrozoobenthos species was almost similar as station I and 16 species were recorded. Sampling station III lies in city and here 
diversity of macrozoobenthic fauna was poor than both the stations and only 13 species were reported.Among all, the phylum Mollusca was in dominant position followed by Annelida and Arthropoda. In Mollusca, gastropods were dominant than Pelecypoda and Bivalvia. Some worker also reported that molluscan communities were dominant at River(Khan et al., 2007; Roy and Gupta, 2010). Riverine condition and habitat structure is being altered due to discharge of domestic sewage and constriction of buildings and dam.

Table 1: Diversity of macrozoobenthos in Sai River at Raebareli, U.P.

\begin{tabular}{|c|c|c|c|c|}
\hline \multirow[t]{2}{*}{ S. No. } & \multirow[t]{2}{*}{ Class/Taxa } & & Sampling sites & \\
\hline & & S1 & $\mathrm{S} 2$ & S3 \\
\hline \multicolumn{5}{|c|}{ Phylum- Annelida (29.16\%) } \\
\hline \multicolumn{5}{|c|}{ Class 1: Oligochaeta } \\
\hline 1. & Branchiurasp. & + & - & + \\
\hline 2. & Limnodrilus sp. & - & + & + \\
\hline 3. & Lumbriculus sp. & + & + & - \\
\hline 4. & Tubifexsp. & + & - & + \\
\hline 5. & Nais sp. & + & + & + \\
\hline \multicolumn{5}{|c|}{ Class 2: Hirudinidae } \\
\hline 6. & Glassiphoniasp & - & + & + \\
\hline 7. & Erpobdella sp. & + & - & + \\
\hline Total & & 5 & 4 & 6 \\
\hline \multicolumn{5}{|c|}{ Phylum-Arthropoda (25.00\%) } \\
\hline \multicolumn{5}{|c|}{ Class 1: Insecta } \\
\hline 8. & Caenis sp. & + & + & - \\
\hline 9. & Chironomussp. & - & + & - \\
\hline 10. & Hydrophilus sp. & + & + & + \\
\hline \multicolumn{5}{|c|}{ Class 2: Crustacaea } \\
\hline 11. & Gammarus sp. & + & + & - \\
\hline \multicolumn{5}{|c|}{ Class 3: Arachnida } \\
\hline 12. & Dolomedessp. & + & - & + \\
\hline 13. & Acari sp.(Water mites) & + & - & + \\
\hline Total & & 5 & 4 & 3 \\
\hline \multicolumn{5}{|c|}{ Phylum- Mollusca (45.83\%) } \\
\hline \multicolumn{5}{|c|}{ Class 1: Gastropoda } \\
\hline 14. & Lymnaea sp. & + & + & - \\
\hline 15. & Pilasp. & + & - & + \\
\hline 16. & Thiarasp. & - & + & + \\
\hline
\end{tabular}




\begin{tabular}{|l|l|c|c|c|}
\hline 17. & Gyraulus sp. & + & - & + \\
\hline 18. & Tarebiasp. & + & - & + \\
\hline 19. & Bellamyasp. & + & + & - \\
\hline Class 2: Pelecypoda & - & + & + \\
\hline 20. & Corbicula sp. & + & - & + \\
\hline 21. & Planorbula sp. & + & - & - \\
\hline 22. & Promentussp. & & & + \\
\hline Class 3: Bivalvia & Lamellidenssp. & + & - & + \\
\hline 23. & Parreysia sp. & $\mathbf{8}$ & $\mathbf{5}$ & - \\
\hline 24. & Total & $\mathbf{1 8}$ & $\mathbf{1 3}$ & $\mathbf{1}$ \\
\hline
\end{tabular}

\section{CONCLUSION}

The present investigation depicted about the distribution and diversity of macrozoobenthos in the three sites of Sai river at Raebareli and reported about the loss of macrozoobenthic distribution in the city site and downstream due to construction of building which causes habitat alterations. During the study, it was observed that at sampling site I, the diversity of macrozoobenthos fauna was highest than II and III. Riverine condition and habitat structure is being altered due to intake of domestic sewage water and shows that in near future ecology this river will be much affected. The study revealed about the future research prospects in this area for studying the impact of pollution on the ecology of River Sai.

\section{REFERENCES}

1. Ankar, S. and Elmgreen (1976). The benthic macro- and microfauna of the Askoe-Landsort area (northern Baltic proper). A stratified random sampling survey. Contrib. Asko Lab.11:1-115.

2. Arya S. (2021). Freshwater Biodiversity and Conservation Challenges: A Review. International Journal of Biological Innovations. 3 (1): 74-78.

3. Ashok K.V. (2016). Biodiversity: Its Different Levels and Values. International Journal on Environmental Sciences. 7(2): 143-145.

4. Ashok K.V. (2017). Genetic Diversity as Buffer in Biodiversity. Indian Journal of Biology. 4(1): 61-63.
5. Borror Donald, J., Delongdwilight, M. and Triplehorn, Charles, A. (1976). An introduction to the study of Insects. $4^{\text {th }}$ edition. Library of congress cataloging in Publication, USA.

6. Chakraborty B. K., Bhattacharjee S. and Muniya S. (2021a). A Study on Aquatic Biodiversity of Shuthi-Shaiduli River of Bangladesh. International Journal of Biological Innovations. 3(1): 58-67.

7. Chakraborty B. K., Verma A. K. and Muniya S. (2021b). Present Status of Aquatic Resource and Its Catch of Mogra River in Bangladesh. Sustainable Marine Structures. 3 (2): 26-38.

8. Goswami D. N., Gautam Y.P. and Kumar A. (2021). Evaluation of Ganges water quality and its suitability for Agriculture use from Rishikesh to Prayagraj, India. International Journal of Biological Innovations. 3(2):417-421.

9. Kalal V., Giri M.J., Baskar S. and Kuba R. (2021). Detection of Pollutants present in the surface water of Ayad River, Udaipur, Rajasthan. International Journal of Biological Innovations. 3 (1): 212-220.

10. Khan, A.N., Kamal, D., Mahmud, M.M., Rahman, M.A. and Hossain, M.A. (2007). Diversity, distribution and abundance of benthos in Mouri River, Khulna, Bangladesh, Int. J. Sustain. Crop Prod., 2(5), 19- 23.

11. Kumar, Ajay and Verma, A.K. (2017). Biodiversity loss and its Ecological impact in 
India. International Journal on Biological Sciences. 8(2): 156-160.

12. Mandal, A. C. and Singh, O.P. (2020). Climate Change and Practices of Farmers' to maintain rice yield: A case study. International Journal of Biological Innovations. 2(1): 42-51.

13. Needham, J.G. and Needham, P.R. (1962). A guide to study the freshwater biology HaldenDaylnc San Francisco.1-232.

14. Pennak, R.W. (1989). Fresh invertebrates of the United States. Protozoan to mollusca Johan Wilx and Sons, NY.

15. Piper, C.S. (1966). Soil and Plant Analysis. Hans Publication, Bombay.

16. Prakash S. (2020a). Fish diversity of Semara Taal, a wetland of district Siddharthnagar (U.P.), India. International Journal of Fisheries and Aquatic Research.5(2):07-09.

17. Prakash S. (2020b). Conservation status of fishes reported from Semara Taal of District Siddharthnagar (U.P.). India. International Journal of Fauna and Biological Studies. 7(3): 21-24.

18. Prakash S. (2020c). Population Dynamics of Macrozoobenthos of GuathiaTaal, A Wetland of District Bahraich, U.P. (India). Journal of Entomology and Zoology Studies. 8(4): 17601764.

19. Prakash S. (2021). Impact of Climate change on Aquatic Ecosystem and its Biodiversity: An overview. International Journal of Biological Innovations. 3(2):312-317.

20. Prakash, S. and Srivastava, S. (2019).Impact of Climate Change on Biodiversity: An Overview. International Journal of Biological Innovations. 1(2): 60-65.

21. Prakash, S., Kumar, A., Prakash, S. and Mishra, B.K. (2020).A Survey of Fish Fauna of Rapti River, Balrampur (U.P.), India. International Journal of Biological Innovations. 2(1): 76-81.

22. Rani, D. and Kumar, A. (2020). Fish diversity of Sai River flowing Raebareli district of Uttar Pradesh (India). International Journal of Fisheries and Aquatic Studies. 8(5):182-185.
23. Roy S. and Gupta A. (2010). Molluscan Diversity in River Barak and its Tributaries, Assam, India. Assam University Journal of Science and Technology: Biological and Environmental Sciences. $5(1), 109-113$.

24. Sanjay, M.C. and Prakash, S. (2020). Ichyofaunal Diversity of Rapti River flowing through Shravasti and Balrampur districts of Uttar Pradesh (India). Bulletin of Pure and Applied Sciences. 39A(Zoology)2:272-280.

25. Singh P.R. and Verma A.K. (2016). Observations on Hydrobiological Conditions of River Ganga at Daraganj, Allahabad. The Journal of Zoology Studies. 3(4): 81-82.

26. Singh. V. and Prakash, S. (2021). Macrozoobenthos diversity of Bhagdataal, a wetland of Balrampur, U.P. (India). Bulletin of Pure and Applied Sciences. Zoology. 49(1):157163.

27. Siraj, S., Yousuf, A. R., Bhat, F. A. and Parveen, M. (2010).The ecology of macrozoobenthos in Shallabugh wetland of Kashmir Himalaya, India. Journal of Ecology and the Natural Environment. 2(5), pp. 84-91,

28. Subbiah, B.V. and Asija, G.L. (1956). A rapid method for estimation of nitrogen in soil. Curr. Sc.26:259-260.

29. Sugumaran E., Shabeen B. and Radhakrishnan M.V. (2020). Zooplankton Diversity in Sathanur Reservoir of Thiruvannamalai (Tamilnadu), India. International Journal of Biological Innovations. 2 (2): 95-101.

30. Thoker, M.I., Gupta, R. Najar, M.A. and Zuber, S.M. (2015). Macrozoobenthos community Pattern and diversity in relation to water quality statusof stream Rambiara. International Journal of Fisheries and Aquaculture Sciences. 5(1):91-100.

31. Trivedy, P.K., Goel, P.K. and Trisal, C.L. (1987). Practical Methods in Ecology and Environmental Science. Environmental Publication, Karad.

32. Verma A. K. (2016a). Hydrobiological Studies of Muntjibpur Pond of Allahabad (U.P.). International Journal on Agricultural Sciences. 7(2): 164-166. 
33. Verma A.K. (2016b). A Preliminary Survey of Fresh Water Fishes in Muntjibpur Pond of Allahabad (U.P.). Indian Journal of Biology. 3(2): 99-101.

34. Verma, A.K. (2017). Necessity of Ecological Balance for Widespread Biodiversity. Indian Journal of Biology. 4(2): 158-160.

35. Verma, A. K. (2018a).Unsustainable Agriculture, Environmental Ethics and Ecological Balance. HortFlora Research Spectrum. 7 (3): 239-241.

36. Verma, A.K. (2018b). Ecological Balance: An Indispensable Need for Human Survival. Journal of Experimental Zoology, India. 21 (1): 407-409.

37. Verma A.K. (2020). Limnological Studies of Muntjibpur pond of Prayagraj (U.P.) in relation to planktons. International Journal of Fauna and Biological Studies. 7 (4): 27-30.

38. Verma A.K. (2021). Influence of climate change on balanced ecosystem, biodiversity and sustainable development: An overview. International Journal of Biological Innovations. 3(2):331-337. https://doi.org/ 10.46505/ IJBI.2021.3213

39. Verma, A.K. and Prakash, S. (2018). Qualitative and quantitive analysis of macrozoobenthos of BeghelTaal, a wetland of U.P. Indian Journal of Biology. 5 (2): 127-130.

40. Verma A.K. and Prakash S. (2020). Status of Animal Phyla in different Kingdom Systems of Biological Classification. International Journal of Biological Innovations. 2 (2): 149-154. 